OPEN ACCESS

Edited by:

Tida Ge,

Ningbo University, China

Reviewed by:

Vipin Sharma,

Sagar Institute of Research and

Technology (SIRT), India

Behzad Sani,

Islamic Azad University, Iran

*Correspondence:

Linda Yuya Gorim

gorim@ualberta.ca

Specialty section:

This article was submitted to

Plant-Soil Interactions,

a section of the journal

Frontiers in Agronomy

Received: 04 January 2022

Accepted: 27 January 2022

Published: 02 March 2022

Citation:

Ampong K, Thilakaranthna MS and Gorim LY (2022) Understanding the

Role of Humic Acids on Crop

Performance and Soil Health.

Front. Agron. 4:848621.

doi: 10.3389/fagro.2022.848621

\section{Understanding the Role of Humic Acids on Crop Performance and Soil Health}

\author{
Kwame Ampong, Malinda S. Thilakaranthna and Linda Yuya Gorim* \\ Department of Agricultural, Food and Nutritional Science, University of Alberta, Edmonton, AB, Canada
}

Humic acids $(\mathrm{HA})$ are organic molecules that play essential roles in improving soil properties, plant growth, and agronomic parameters. The sources of HA include coal, lignite, soils, and organic materials. Humic acid-based products have been used in crop production in recent years to ensure the sustainability of agriculture production. Reviewed literature shows that HA can positively affect soil physical, chemical, and biological characteristics, including texture, structure, water holding capacity, cation exchange capacity, pH, soil carbon, enzymes, nitrogen cycling, and nutrient availability. This review highlights the relevance of HA on crop growth, plant hormone production, nutrient uptake and assimilation, yield, and protein synthesis. The effect of HA on soil properties and crops is influenced by the HA type, HA application rate, HA application mode, soil type, solubility, molecular size, and functional group. This review also identifies some knowledge gaps in HA studies. HA and its application rate have not been tested in field experiments under different crops in rotation, nitrogen fertilizer forms, sites and climatic conditions. Furthermore, HA chemical and molecular structures, their water and alkaline soluble fractions have not been tested under field experiments to evaluate their effects on crop yield, quality, and soil health. The relationship between soil-plant nutrient availability and plant nutrient uptake following HA application should also be further studied.

Keywords: humic acids, humic substances, plant growth, agronomic parameters, soil properties, nutrient availability

\section{INTRODUCTION}

Humic substances (HS) are remains of decomposed plant and animal materials such as lignin, tannins, cellulose, and cutins (Tan et al., 2000; Billingham, 2012; Hayes and Swift, 2020). High quantities of HS are present in the soil after incorporating harvested residues (Wiesler et al., 2016). Increased animal and biogas production have reduced the amount of harvested residues on most arable land, resulting in decreased HS in the soil. Over the past decades, researchers have attempted to replenish the decreased HS with external applications (Rose et al., 2014; Gerke, 2018). The external sources of HS are mostly commercially produced from soils, coal, lignite, and organic materials (Gollenbeek and Van Der Weide, 2020; Yang et al., 2021).

HS are classified as humic acids (HA), fulvic acids (FA), and humins based on their solubility in water, acidic or alkaline solutions (De Melo et al., 2016). Due to the non-degrading nature of the humin fraction in HS, researchers have focused on the HA and FA fractions because they are capable of improving soil fertility and health within short time frames. The HA and FA fractions of HS are chemically reactive and able to resist microbial reactions, thereby 
performing beneficial roles in soils and plants (Billingham, 2012). The ability of HA to withstand degradation for long periods and their amphiphilic properties enable them to form complex cations (Wood, 1996). HA fraction contains about $60 \%$ organic carbon (C), which plays an important role in the growth of soil microorganisms (Sible et al., 2021). In addition to C, HA also contain nitrogen $(\mathrm{N})$, oxygen $(\mathrm{O})$, hydrogen $(\mathrm{H})$, and sulfur $(\mathrm{S})$.

Humic acids play several important roles such as: increase soil physical and biochemical activities by improving structure, texture, water holding capacity (WHC), and microbial population (Nardi et al., 2017, 2021; Fuentes et al., 2018; Shah et al., 2018); increase soil nutrients availability, especially micronutrients by chelating and co-transporting micronutrients to plants (Yang et al., 2021); reduce the transportation of toxic heavy metals by precipitating them, thus reducing toxic heavy metals intake by plants (Wu et al., 2017). Humic acids also increase crop growth by increasing plant growth promoting hormones such as auxin and cytokinin, which aid in stress resistance, nutrients metabolism, and photosynthesis (Billingham, 2012; Rose et al., 2014; Canellas et al., 2020; Laskosky et al., 2020; Nardi et al., 2021; van Tol de Castro et al., 2021). Some studies have also reported no effects on crop growth and soil health following HA application (Albiach et al., 2001; Bybordi and Ebrahimian, 2013; El-Bassiouny et al., 2014; Mukherjee et al., 2014; Kelapa and Banyuasin, 2016). Although high HA doses are associated with enhanced soil physical characteristics (Gollenbeek and Van Der Weide, 2020), their effects on soil chemical characteristics and crops are still uncertain (Rose et al., 2014). In the review by Rose et al. (2014), among the factors analyzed in mostly greenhouse experiments, HA source had significant effects on both root and shoot growth while application rate only significantly affected shoot growth. A review by De Melo et al. (2016) highlighted carboxylic (COOH) and phenolic $(\mathrm{OH})$ groups as predominant HA features that are largely responsible for their functions in the soil. A recent review by Nardi et al. (2021) showed that HA chemical and molecular structures, sources, and application rates are critical for determining their effects on crops and soil. Importantly, HA application can have inconsistent results on yield, possibly due to the different HA biological origins (Sible et al., 2021).

In view of inconsistent results of $\mathrm{HA}$ application on crop agronomic performance due to differences in HA sources and experimental conditions, and the paucity of literature on field experiments compared to laboratory trials, this review sought to understand HA application in agricultural production. The objectives of this review are to (1) identify the effects of HA on crop agronomic performance and soil health parameters in both laboratory and field experiments; (2) identify the factors that affect the efficiency of HA; (3) identify knowledge gaps in HA application on crop performance and soil health.

\section{RELATIONSHIP BETWEEN HUMIC ACIDS STRUCTURE AND FUNCTIONS}

The functions of HA are associated with their structures, which are source dependent (Rupiasih, 2005; Garciá et al., 2016; García et al., 2019; Nardi et al., 2021; van Tol de Castro et al., 2021).
Although HA structure contains many functional groups, the most predominant are phenolic $(\mathrm{OH})$, and carboxylic $(\mathrm{COOH})$ groups (Figure 1) (Nardi et al., 2021). The $\mathrm{COOH}$ and $\mathrm{OH}$ functional groups are mainly responsible for HA functions such as improving soil physical and chemical properties as well as plant growth (Figure 1) (De Melo et al., 2016; Nardi et al., 2021). Dissociation of these functional groups creates polar and nonpolar ends, which are the hydrophilic and hydrophobic parts, respectively (Mirza et al., 2011); both ends play roles in the mechanisms that confer useful HA functions (Figure 2A). The hydrophilic end is primarily involved in chelating functions, while the hydrophobic end is connected with repelling purposes (Billingham, 2012). Once the $\mathrm{OH}$ and $\mathrm{COOH}$ groups dissociate, the polar end of the anionic part forms complexes with cationic metals through electrostatic bonding in the soil, thus retaining these metals in the soil (Figure 2B). The hydrophilic part, which is also water-loving, forms micelle that increases soil WHC. On the other hand, the non-polar end repels water molecules reducing water infiltration and improving clay aggregate stability (Billingham, 2012). A recent study by van Tol de Castro et al. (2021) reports that the aromatic and aliphatic functional groups of HA were responsible for increasing $\mathrm{N}$ uptake and soluble sugars, which resulted in a corresponding yield increase in rice (Figure 1); meanwhile an earlier finding by Garciá et al. (2016) showed that HS aliphatic and aromatic functional groups stimulated root growth in rice seedlings.

Humic acids with low molecular weight (LMW) contain more phenolic and carboxylic functional groups than HA with high molecular weight (HMW) (De Melo et al., 2016). The chelating ability of HA has also been attributed to LMW, which is efficacious in altering the biochemical characteristics of the

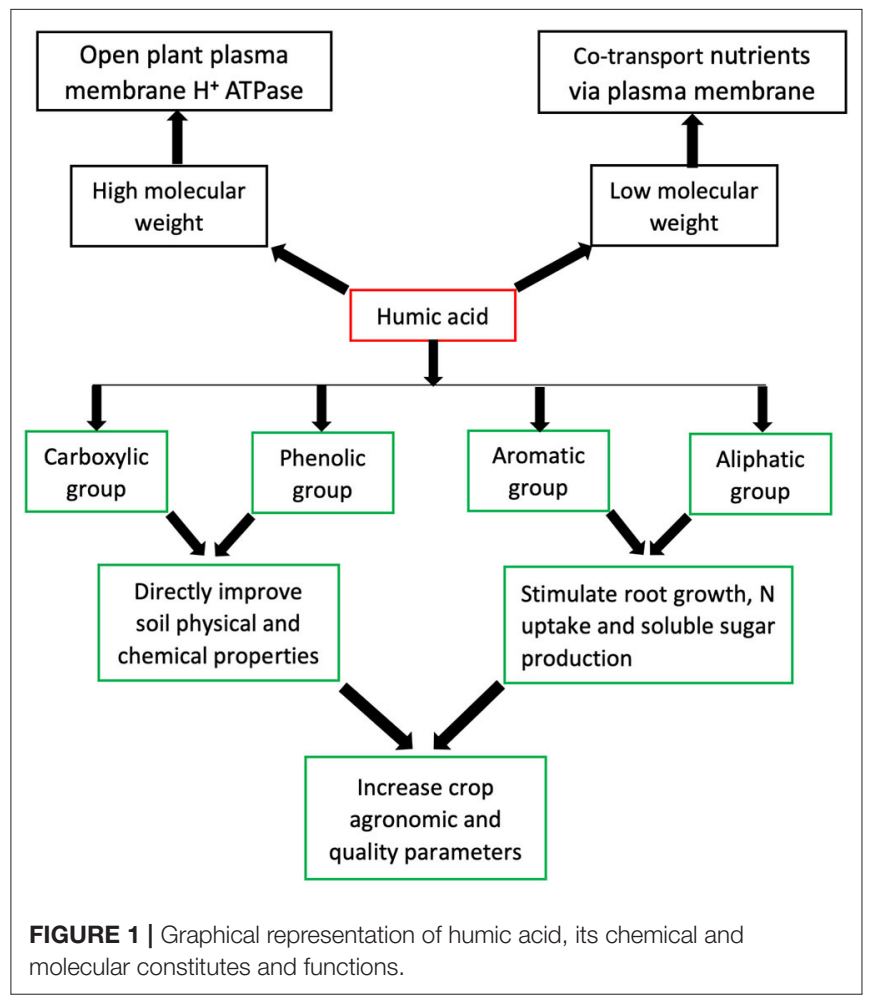


soil, while HMW is efficient in improving the soil physical conditions (Yang and Antonietti, 2020). HA with HMW have also been found to stimulate plasma membrane $\mathrm{H}^{+}$ATPase, allowing LMW HA to co-transport nutrients and perform other biological activities in plants (Figure 1) (Nardi et al., 2021). Enhancement in root growth was also found when both HMW and LMW fractions of HA from vermicompost were applied to both Arabidopsis and maize seedlings (Canellas et al., 2010). A recent review by Nardi et al. (2021) identified that HA molecular size could alter organic acid release in the rhizosphere. A summary of HA chemical and molecular components and functions are presented in Figure 1. More research needs to be conducted to elucidate the interactions of HA structure and organic acids, especially in the rhizosphere, where HA have different interactions with different crops. Furthermore, studies need to be carried out on how the molecular size of HA affects the release of root exudates considering that HA stimulating effect on roots' plasma membrane has been reported (Nardi et al., 2021).

\section{EFFECT OF HUMIC ACIDS ON SOIL AND PLANTS}

\section{Soil Texture, Structure, and Water Holding Capacity}

The continuous practice of tillage and planting on the same land every year has a negative effect on soil texture and structure. The application of HA has been reported to have positive effects on the texture and structure of degraded soils (Billingham, 2012; Yang et al., 2021). The effect of HA on soil properties is summarized in Table 1. Soil structural stability has been attributed to increased adsorption of HA onto clay surfaces (Chen et al., 2017). The addition of HA leads to the formation of chelates with cationic metals (Yamaguchi et al., 2004; Billingham, 2012). These metals act as a bridge between HA and clay surfaces, thereby forming complexes (Figure 2B). For example, the application of bentonite-humic acid increased the macro-aggregates of degraded sandy soil in a 7-year continuous cropping with maize (Zhou et al., 2019). The application of potassium humate increased aggregate stability in both bulk loamy acidic and sodic soils in a controlled study (Imbufe et al., 2005). In a similar experiment conducted by Piccolo et al. (1997), coal-derived humic acid increased soil structure stability irrespective of soil type in controlled wetting/drying experiments for $24 \mathrm{~h}$.

Lack of positive responses following HA application have also been reported. Albiach et al. (2001) found that continuous application of commercially-produced HA had no significant effect on soil aggregate stability after 5 years of continuous cropping on sandy-silty-loam soil. Similarly, the application of coal-produced HA did not improve soil aggregate stability after two growing cycles of corn (Mukherjee et al., 2014). In both aforementioned experiments, the amount of HA applied was not sufficient to cause a change in soil texture and structure, as suggested by the authors. Furthermore, the soil used in the aforementioned studies were neutral to alkaline soils, which could negatively affect bridging humic molecules in HA, as demonstrated in the review by Gerke (2018). The HA source influences soil texture and structure (Rose et al., 2014). Therefore, it will be imperative for researchers to test the efficiency of a single HA source without extrapolating the results to other sources.

Humic acids have also been reported to increase soil WHC (Billingham, 2012; Yang et al., 2021). The water-attracting hydrophilic part of HA and improved soil structure increase soil WHC. It has also been reported that the combined application of HA and FA has a high chance of forming colloids or humicclay complexes, resulting in increased WHC (Billingham, 2012). In a 7-year field experiment to test the effect of bentonite HA on WHC, the application of $30 \mathrm{Mg} \mathrm{ha}^{-1}$ significantly increased soil WHC and the increase was more pronounced after the fourth year of the experiment (Zhou et al., 2019). Application of HA has also been shown to increase compatible solutes such as proline and glycine betaine in plants, which is an

TABLE 1 | Summary of humic acids on soil properties.

\begin{tabular}{|c|c|c|c|c|c|}
\hline Source of HA & Soil texture & Function on soil properties & $\begin{array}{l}\text { Type of } \\
\text { experiment }\end{array}$ & $\begin{array}{l}\text { Duration of } \\
\text { experiment }\end{array}$ & References \\
\hline Bentonite & Degraded sandy soil & $\begin{array}{l}\text { Increased macro aggregate stability and } \\
\text { WHC }\end{array}$ & Field & 7 years & Zhou et al., 2019 \\
\hline Potassium humate & Loam & Increased aggregate stability & Laboratory & $24 \mathrm{~h}$ & Imbufe et al., 2005 \\
\hline Raw oxidized coal & $\begin{array}{l}\text { Silty-clay loam, silt } \\
\text { loam and loam }\end{array}$ & Increased structure stability & laboratory & $24 \mathrm{~h}$ & Piccolo et al., 1997 \\
\hline Commercially-produced liquid HA & Sandy-silt loam & No effect on texture and structure & Field & 5 years & Albiach et al., 2001 \\
\hline Coal & Silty-clay loam & No effect on texture and structure & Field & 2 years & Mukherjee et al., 2014 \\
\hline Peat and coal & Silty sand & Increased CEC & Laboratory & NA & Giannouli et al., 2009 \\
\hline Humalite, peat and biochar & NA & Increased CEC, decreased $\mathrm{pH}$ & Laboratory & 2 months & Laskosky et al., 2020 \\
\hline HA fertilizer & NA & No effect on $\mathrm{pH}$, increased soil enzymes & Field & 3 years & Li et al., 2019 \\
\hline Compost and lignite & Sandy silt & Increased carbon sequestration & Laboratory & 3 months & Spaccini et al., 2002 \\
\hline Commercially-produced & Clay & Increased OC and structural stability & Laboratory & 2 months & Gümüs and Seker, 2015 \\
\hline Plant residues and animal manure & Clay & Increased carbon sequestration & Field & 17 years & Loss et al., 2013 \\
\hline
\end{tabular}

CEC, cation exchange capacity; OC, organic carbon; WHC, water holding capacity; NA, Information not available. 


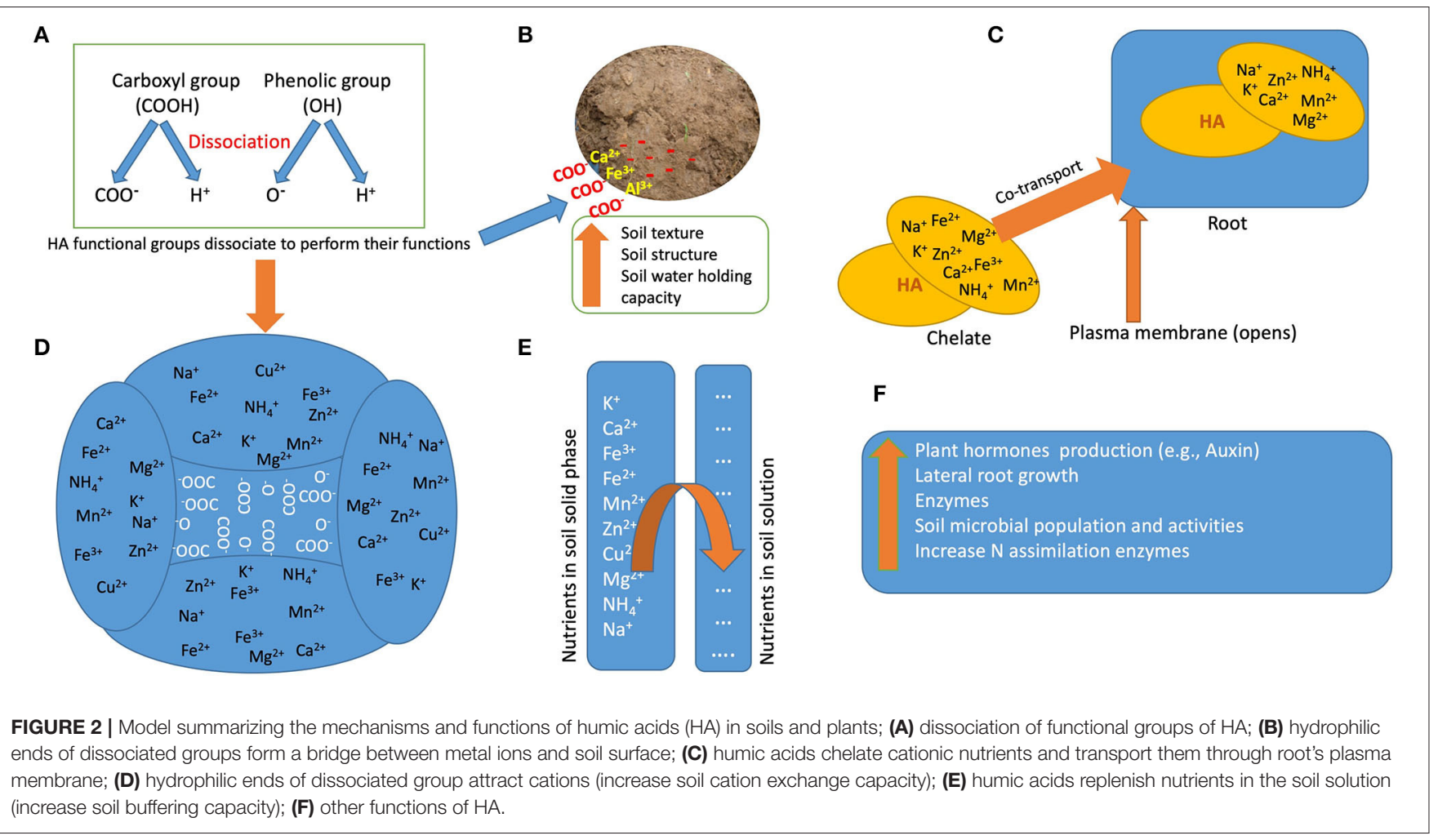

adaptation strategy for plants under water stress (El-Bassiouny et al., 2014).

\section{Soil Cation Exchange Capacity}

The ability of soil to hold nutrients depends on how much cations it can retain. HA have been shown to increase the cation exchange capacity (CEC) of the soil (Figure 2D) (Billingham, 2012). Yang et al. (2021) summarized the contribution of HA in increasing CEC as follows: (1) increasing adsorption of exchangeable cations by providing large surface area for inorganic colloids; (2) dissociation of $\mathrm{COOH}$ and $\mathrm{OH}$ groups to produce polar ends that form complex with cations; and (3) increase dissolution of soil minerals, which create large surface area for chemical reaction. In an incubation experiment in bulk soil to study the effect of 26 different HA produced from peat and coal, all the samples tested increased CEC of amended soil from 1 to 58\% (Giannouli et al., 2009). Surprisingly, there was no linear relationship between the initial CEC of tested samples and the corresponding percentage increase in CEC of amended soils. This may indicate that the CEC of the source material does not directly translate into increased CEC of the amended soil, rather HA quality has an important role on soil CEC. In another study by Laskosky et al. (2020), the effect of humalite, peat, and biochar on CEC of Orthic Gray Luvisol degraded soil was tested in a pot experiment growing barley plants; the residual soil CEC was higher in humalite compared to biochar amended soil. There is no evidence in literature evaluating the effect of HA application on CEC in bulk soil vs. rhizosphere in a single experiment. Most of the research on HA effects on CEC have been conducted under controlled environments and in short-term studies. Therefore, research needs to be conducted to fill in the knowledge gap on HA effect on soil CEC under long term field experiments involving several crops.

\section{Soil pH}

Soil $\mathrm{pH}$ influences nutrient availability. The ability of HA to affect soil $\mathrm{pH}$ changes depends on the amount of carboxylic and phenolic functional groups they contains (Rupiasih, 2005). Few studies have reported changes in $\mathrm{pH}$ with respect to HA application in post-harvest soil analysis. With the limited number of studies, inconsistent results on the effects of HA on soil $\mathrm{pH}$ are reported. In a barley-grown pot experiment with different HA application rates $(0-26.2 \mathrm{~g} / \mathrm{kg})$, post-harvest soil $\mathrm{pH}$ analysis showed a decreasing trend in $\mathrm{pH}$ with increased humalite rates (Laskosky et al., 2020). In a 3-year continuous field cropping experiment involving peanut, HA application did not significantly affect soil $\mathrm{pH}$ (Li et al., 2019). In a hydroponics study involving wheat to study $\mathrm{HA}$ effect on $\mathrm{pH}$ buffering capacity, the application of HA failed to increase the $\mathrm{pH}$ buffering capacity of the nutrient solution with an initial pH of 5.3 (Mackowiak et al., 2001); the authors attributed this failure to low HA concentration applied. Pertusatti and Prado (2007) in a lab assessment showed that HA buffer $\mathrm{pH}$ changes at $\mathrm{pH}$ between 5.5 and 8 . Overall, the effect of HA on $\mathrm{pH}$ is dependent on the experimental conditions, plant grown and HA source. Studies needs to be conducted to elucidate the ideal condition specific for every HA source to identify its effect on soil $\mathrm{pH}$ changes. 


\section{Soil Carbon and Enzymatic Activities}

Soil $\mathrm{C}$ content can be a direct measure of soil health. Carbon emission resulting in climate change and its adverse effects on the environment has resulted in research focused on soil $\mathrm{C}$ sequestration. HS have been reported to be an important pool of short- and long-lived soil C (Rupiasih, 2005). Although HA and FA fractions are decomposable in nature, their break down is slow, resulting in a constant supply of $\mathrm{C}$ to the soil. In the review by Sible et al. (2021), HA contain a high amount of $\mathrm{C}$ compared to FA. This indicates that the application of HA may provide additional $\mathrm{C}$ to soil microorganisms, essential for soil biological activities. The supply of $C$ to the soil after HA application depends on the decomposition rate, turnover, and residence time in the soil (Fontaine et al., 2007). HA are supposed to undergo further transformational changes into smaller molecular sizes after soil application (Grinhut et al., 2007). It has been reported that HA turnover is contingent upon how synergistically plants and microorganisms combine in offering the needed priming effect (Dungait et al., 2012). In addition to the interaction between plants and microorganisms, environmental factors such as $\mathrm{pH}$, moisture, oxygen, and $\mathrm{HS}$ properties affect HA decomposition rate (Dungait et al., 2012).

There have been numerous studies on the effect of HA application on soil C storage. In a 3-month soil incubation study with ${ }^{13} \mathrm{C}$ labeling technique to study the effect of $\mathrm{HA}$ addition on $\mathrm{C}$ sequestration, up to $58 \% \mathrm{C}$ added was retained (Spaccini et al., 2002). The increase in $\mathrm{C}$ sequestration was a function of the HA chemical properties; the higher the hydrophobicity of the HA material, the higher the increase in $\mathrm{C}$ sequestration. Using incubation studies, Gümüs and Seker (2015) also found that the application of HA increased organic C content in clayey soil, where improvement in soil $\mathrm{C}$ depends on the HA application rate. In another study involving brachiaria/livestock and pearl millet/no livestock rotational system on clayey soil in Brazil, it was found that management systems that had a higher HA fraction had higher C sequestration (Loss et al., 2013). The application of HA-rich vermicompost significantly increased C sequestration in sandy-loam soil compared with NPK and soil alone treatments, through the increase in microbial biomass $\mathrm{C}$ and population, after 60 days of pea grown indoors (Maji et al., 2017). Most studies report on HA effects on total carbon pool but not labile and recalcitrant $\mathrm{C}$. To our knowledge, only one study has reported the effect of HA from organic waste on labile and recalcitrant $\mathrm{C}$ in humus-rich soil under field conditions (Hu et al., 2019). They showed that soil supplements high in HA negatively correlated with labile $\mathrm{C}$ but had a significant and positive correlation with recalcitrant $\mathrm{C}$ in the soil. The paucity of literature on $\mathrm{HA}$ effects in long term field studies involving crops in rotations and post-soil analysis of $\mathrm{C}$ pool fractions warrants further research (Olk et al., 2018).

Humic acid application has been reported to increase microbial population and activities (Maji et al., 2017; Li et al., 2019). In a 3-year continuous cropping with pea to investigate HA effects on soil enzymatic activity, application of $1,000 \mathrm{Kg}$ $\mathrm{ha}^{-1}$ HA significantly increased urease, phosphatase and sucrase activity after 140 days of plant growth under greenhouse conditions (Li et al., 2019). In the same vein, the application of
9,000 $\mathrm{Kg} \mathrm{ha}^{-1} \mathrm{HA}$-rich vermicompost in a pot experiment with pea significantly increased urease activity after 12 days of plant growth (Maji et al., 2017). In both experiments, the microbial population and $\mathrm{C} / \mathrm{N}$ ratio increased, resulting in increased urease activity. In contrast, Shen et al. (2020b) found in a soil incubation experiment that HA application from weathered coal inhibited urease activity. Similarly, urease activity was inhibited when HA produced from Leonardite was investigated in soil incubation experiments (AL-Kanani et al., 1990). The microbial biomass was not determined in the previous two experiments by AL-Kanani et al. (1990) and Shen et al. (2020b), but less biological activity in bulk soil may have reduced microbial biomass and subsequent reduction in urease activity (Elmajdoub et al., 2014). Tomar and MacKenzie (1984) also suggested that HMW and enzyme binding by HA carboxylic and phenolic functional groups may inhibit urease activity. More research needs to be conducted to better understand HA effects on soil enzymatic activities involving different crops under field conditions in different soil types.

\section{Urea Hydrolysis, Ammonification, and Nitrification}

Urea is the most common $\mathrm{N}$ fertilizer used by crop producers due to its cost-effectiveness. For urea to be available for plant uptake, it has to be hydrolyzed into ammonium. Subsequent nitrification and de-nitrification convert ammonium into nitrate and nitrogen gases, respectively (Shen et al., 2020b). Unlike nitrate that is prone to leaching in the soil due to its hydrophobic nature, ammonium is stable in the soil (Oelmann et al., 2007). Plants can take up $\mathrm{N}$ in the form of ammonium and nitrate (Ups et al., 1990). The rapid conversion of ammonium to nitrate has been a major concern for agronomists as the latter has been shown to decrease nitrogen use efficiency (NUE) (AL-Kanani et al., 1990; Barth et al., 2020). The hydrolysis of urea is catalyzed by urease enzymes, which are produced by microorganisms in the soil (Tomar and MacKenzie, 1984). The rate of urea hydrolysis has also been linked to high concentrations of nickel (Tan et al., 2000). Due to the chelating properties of HA, it is able to form complex nickel, thus slowing down urea hydrolysis (Sible et al., 2021).

However, various studies have shown contradictory results on HA effects on urea hydrolysis (AL-Kanani et al., 1990; Maji et al., 2017; Li et al., 2019). In a 90-day soil incubation experiment to study the effect of coal-produced HA on urea transformation, HA application reduced urea hydrolysis by twofolds compared to the control (Shen et al., 2020b). In the same study, soil ammonium concentration was stable until the third day, after which it reduced drastically; the reduction in soil ammonium concentration reflected a corresponding increase in soil nitrate concentration. In a similar experiment by ALKanani et al. (1990), the application of up to $3.4 \%$ HA produced from Leonardite resulted in a $5-22 \%$ increase in urea hydrolysis in Typic Hapludoll and Typic Cryochrept soils. In all the aforementioned experiments, there was a decrease in $\mathrm{pH}$ in HAtreated soils. It has also been shown that HA application reduces soil nitrifying microorganisms, thereby increasing ammonium concentration and reducing soil nitrification rate (Dong et al., 2009). In a pot experiment grown with barley to study the 
effect of biochar, peat and humalite on urea hydrolysis and nitrification in the rhizosphere, humalite containing higher HA increased hydrolysis of urea into ammonium, while reducing nitrification of ammonium to nitrate (Laskosky et al., 2020). The high ammonium retention in the humalite treatment further resulted in increased CEC and decreased $\mathrm{pH}$. It is important to note that HA used in different studies had different chemical and structural composition and application rates. Therefore, it will be interesting to investigate the effect of HA sources and application rate on urea hydrolysis and subsequent nitrification and denitrification in different crops under defined growth conditions.

\section{Soil Nutrients Availability and Uptake by Plants}

HA ability to increase soil nutrients availability and uptake by plants have been summarized in Figures 2A-F. Many studies have shown the ability of HA to stabilize ammonium, which improves soil $\mathrm{N}$ availability (Ahmed et al., 2006; Dong et al., 2009; Rose et al., 2014; Zhang et al., 2019; Laskosky et al., 2020; Shen et al., 2020b). Nitrogen is also present in HA molecules which becomes available to plants after soil application (Billingham, 2012). Plants mostly take up $\mathrm{N}$ in the form of inorganic ammonium and nitrate, but also $\mathrm{N}$ in the form of amino acids (Nardi et al., 2002). HA N uptake in higher plants depends on their molecular size and carboxylic group (Nardi et al., 2000). Piccolo et al. (1992) showed that $\mathrm{N}$ uptake was positively correlated with LMW and the amount of carboxylic functional group of HA. Tavares et al. (2019) studied the effect of vermicompost $\mathrm{HA}\left(80 \mathrm{mg} \mathrm{L}^{-1}\right)$ on $\mathrm{N}$ uptake after exposing rice plants to ammonium and nitrate for $48 \mathrm{~h}$; vermicompost significantly increased ammonium and nitrate uptake.

Apart from N, phosphorus (P) is also an essential nutrient, which synergistically increases crop growth and yield. The application of HA and FA has been shown to increase phosphatase activity by soil microorganisms, resulting in increased soil P solubilization (Sharma et al., 2013). HA also reduce sorption and increase desorption of soil phosphate ions, thereby increasing $\mathrm{P}$ in soil solution (Zhu et al., 2018). HA chelates soil micronutrients and co-transport them into plants (Figure 2C) (Sible et al., 2021). However, HA ability to chelate micronutrients and co-transport them into plants depends on HA molecular weight (Zanin et al., 2019). HA also increase the permeability of the plasma membrane, which serves as the point of nutrient absorption (Figure 2C) (Nardi et al., 2002). The higher the rate of HA applied, the higher CEC of the amended soil (Laskosky et al., 2020). While high doses of HA may improve the physical properties of the soil, its high binding capacities can also render some nutrients, especially micronutrients, unavailable for plant uptake. HA carboxylic and phenolic groups act as metalchelating agents that form metal-humic complexes in the soil, which may increase the presence of soil micronutrients but decrease their availability for plant uptake (Yang et al., 2021). For example, it is suggested by Shen et al. (2020a) that high doses of HA bind strongly to heavy metals such as iron, zinc and manganese in the soil, thereby limiting them for plant uptake. The application of potassium humate (up to $20 \mathrm{~kg} \mathrm{ha}^{-1}$ ) in a rice field experiment increased soil micronutrients content, but these micronutrients were not available for plant uptake (Nandakumar et al., 2004). In another study, the application of $10 \mathrm{ml} / \mathrm{L} \mathrm{HA}$ produced from Leonardite plus $30 \mathrm{ml}$ Hoagland solution, did not significantly increase micronutrients and calcium uptake in broad bean (Bulut and Akinci, 2010). HA effects on soil micronutrients availability and plant uptake cannot be assumed to be a positive linear relationship due to differences in HA chemical and physical composition. Therefore, research needs to be conducted to elucidate the relationship between HA rates, nutrient availability, and plant uptake.

\section{Nitrogen Assimilation and Protein Content in Plants}

Nitrogen is very important nutrient for plants growth, yield and yield quality. Plants' ability to take up $\mathrm{N}$ is the first critical step of $\mathrm{N}$ assimilation processes in plants. $\mathrm{N}$ metabolism in plants is dependent on enzymes, which reduce $\mathrm{N}$ forms taken up by plants into final assimilatory products. In a 2 -week hydroponics study, the application of different HA concentrations $\left(0,1,5 \mathrm{mg} \mathrm{L}^{-1}\right)$ significantly increased enzymes involved in the reduction and assimilation processes of $\mathrm{N}$ in maize in a dose-dependent manner (Vaccaro et al., 2015). Surprisingly, the dose-dependent increase in these enzymes did not reflect in the leaf protein content of maize; the low HA level had significantly higher protein content. The genes encoding these enzymes are mediated by nitrate supply (Vaccaro et al., 2015). In a similar study involving an 8-week pot experiment with lettuce by Haghighi et al. (2012), the application of up to $1,000 \mathrm{mg} \mathrm{L}^{-1} \mathrm{HA}$ increased nitrate concentration and nitrate reductase in a dose-dependent manner. Unlike the study by Vaccaro et al. (2015), Haghighi et al. (2012) showed increase in protein content that was positively correlated with HA application rates. Inconsistent results have been reported on the application of HA on grain protein content. The application of up to $400 \mathrm{~g}$ liquid HA without base fertilizer in a field experiment significantly increased millet protein concentration relative to untreated control (Saruhan et al., 2011); when the mode of application was compared, soil and leaf application had the highest protein concentration than seed application. However, foliar application of up to $400 \mathrm{mg} \mathrm{L}^{-1} \mathrm{HA}$ did not have significant effect on millet protein content in field experiments (Shen et al., 2020a). In another 2-year field experiment in Iran to evaluate the effect of foliar application of HA and different urea levels, the treatments did not significantly increase wheat protein and gluten content (Nasiroleslami et al., 2021). Soil application of $1,000 \mathrm{~kg} \mathrm{ha}^{-1} \mathrm{HA}$ significantly increased peanut protein content in the first growing year compared with only urea treatment but did not have a significant effect on protein content in the last 2 years of field experiments (Li et al., 2019). Literature suggests that HA positively affect crop $\mathrm{N}$ uptake irrespective of the amount and form of $\mathrm{N}$ applied, but the assimilation process depends on the $\mathrm{N}$ form. Reviewed literature also suggests that HA have different effects on protein content depending on the amount of HA applied, application mode, and crop type. The lack of a clear pattern on $\mathrm{N}$ assimilation and crop protein content may be a function of HA type on enzymes that are involved in the 
TABLE 2 | Summary of humic acids effects on crop agronomic parameters.

\begin{tabular}{|c|c|c|c|c|c|c|c|}
\hline Source of HA & Source of $\mathbf{N}$ & Soil texture & Crop type & $\begin{array}{l}\text { Functions on crop agronomic } \\
\text { parameters }\end{array}$ & $\begin{array}{l}\text { Type of } \\
\text { experiment }\end{array}$ & $\begin{array}{l}\text { Duration of } \\
\text { experiment }\end{array}$ & References \\
\hline Vermicompost & $\begin{array}{l}\mathrm{NH}_{4}, \mathrm{NO}_{3} \\
\text { urea }\end{array}$ & $\begin{array}{l}\text { Soilless, } \\
\text { sandy loam }\end{array}$ & $\begin{array}{l}\text { Cucumber, } \\
\text { peat, tomato }\end{array}$ & $\begin{array}{l}\text { Increased shoot and root weight, } \\
\text { height, leaf area }\end{array}$ & Laboratory & 4 months & $\begin{array}{l}\text { Atiyeh et al., 2002; } \\
\text { Maji et al., } 2017\end{array}$ \\
\hline Commercial & Manure & Silty-clay & Pepper & $\begin{array}{l}\text { Increased chlorophyll b, fruit weight, } \\
\text { and yield }\end{array}$ & Laboratory & 2 years & $\begin{array}{l}\text { Karakurt et al., } \\
2009\end{array}$ \\
\hline Leonardite & $\mathrm{NH}_{4}, \mathrm{NO}_{3}$ & Sandy loam & $\begin{array}{l}\text { Canola, Green } \\
\text { beans, Wheat, } \\
\text { Gerbera }\end{array}$ & $\begin{array}{l}\text { Increased Gerbera plant root } \\
\text { biomass, canola shoot yield but no } \\
\text { effect on wheat and beans }\end{array}$ & Laboratory & 1 year & $\begin{array}{l}\text { Akinremi et al., } \\
\text { 2000; Nikbakht } \\
\text { et al., } 2008\end{array}$ \\
\hline Organic waste & NA & NA & $\begin{array}{l}\text { Chrysanthe- } \\
\text { mum }\end{array}$ & $\begin{array}{l}\text { Increased chlorophyll content, leaf } \\
\text { area, root and shoot weight }\end{array}$ & Laboratory & 2 months & Fan et al., 2014 \\
\hline Lignite & Urea & Silty loam & Wheat & $\begin{array}{l}\text { Increased root and shoot weight, } \\
\text { chlorophyll content, and yield }\end{array}$ & Laboratory & 2 years & $\begin{array}{l}\text { Arjumend et al., } \\
2015\end{array}$ \\
\hline NA & NA & Clayey & Wheat & $\begin{array}{l}\text { Increased height, spike length, } 1000 \\
\text { grain weight, and yield }\end{array}$ & Field & 2 years & Khan et al., 2010 \\
\hline Commercial & $\mathrm{NH}_{4}, \mathrm{NO}_{3}$ & Sandy & Wheat & $\begin{array}{l}\text { Increased root and shoot weight, and } \\
\text { chlorophyll content but not height, } \\
\text { yield and protein }\end{array}$ & Field & 2 years & $\begin{array}{l}\text { El-Bassiouny } \\
\text { et al., } 2014\end{array}$ \\
\hline Commercial & $\mathrm{NH}_{4}, \mathrm{NO}_{3}$ & Loamy & $\begin{array}{l}\text { Stevia } \\
\text { rebaudiana }\end{array}$ & Increased shoot yield & Field & 2 years & $\begin{array}{l}\text { Mohammed et al., } \\
2019\end{array}$ \\
\hline Commercial & Urea & Loamy & Wheat & $\begin{array}{l}\text { Increased spike number, yield but not } \\
\text { protein content }\end{array}$ & Field & 2 years & $\begin{array}{l}\text { Nasiroleslami } \\
\text { et al., } 2021\end{array}$ \\
\hline Zeolite & Urea & Loamy & Canola & $\begin{array}{l}\text { Increased 1,000 grain weight, yield, } \\
\text { and protein content }\end{array}$ & Field & 2 years & $\begin{array}{l}\text { Bybordi and } \\
\text { Ebrahimian, } 2013\end{array}$ \\
\hline NA & NA & NA & Millet & No effect except yield & Field & 2 years & Shen et al., 2020a \\
\hline
\end{tabular}

NA, Information not available.

metabolic process but more research is warranted in order to get a clear picture.

\section{Plant Agronomic Parameters}

The effect of HA on crop agronomic parameters has been summarized in Table 2. Various studies have been conducted to evaluate HA effects on plant growth and agronomic parameters such as root and shoot growth, leaf chlorophyll content, and yield. HA have been shown to stimulate root and shoot growth by enhancing the production of plant growth-promoting hormones such as auxin and cytokinin, and metabolic enzymes (Rose et al., 2014; Olaetxea et al., 2020). The improved uptake of macro and micronutrients following HA application increase the leaf chlorophyll concentration, which positively affect shoot growth (Chen et al., 2004; Fan et al., 2014; Sible et al., 2021). The production of plant hormones and enzymes as well as the increase in root and shoot weight, chlorophyll content, and photosynthetic rate following HA application, have been shown to improve yields (Delfine et al., 2005; Bybordi and Ebrahimian, 2013). Atiyeh et al. (2002) found that, the application of HA-rich vermicompost at rates between 0.15 and $0.4 \mathrm{~g} \mathrm{~kg}^{-1}$ significantly increased the height and leaf area of cucumber seedlings; higher concentrations failed to increase the root and shoot dry weight. Also, the application of HA-rich vermicompost significantly increased the length/height and weight of roots and shoots of pea compared to NPK treatment alone (Maji et al., 2017). In a related study, HA application up to $40 \mathrm{ml} \mathrm{L}^{-1}$ did not significantly affect the "chlorophyll a" concentration but increased "chlorophyll b" concentration, fruit weight, and yield of pepper (Karakurt et al., 2009). Application of Leonarditederived HA in greenhouse experiments increased the root and shoot biomass of Gerbera and canola, respectively (Akinremi et al., 2000; Nikbakht et al., 2008). The application of HA derived from organic waste significantly increased agronomic parameters of chrysanthemum including the chlorophyll content, leaf area, and root and shoot dry weight (Fan et al., 2014). Arjumend et al. (2015) reported a significant effect of different HA rates and recommended NPK mineral fertilizer on shoot and root weight, chlorophyll content, thousand grain weight, and grain yield in wheat.

In a field experiment, Khan et al. (2010) reported that different HA rates and NPK significantly increased wheat plant height, spike length, thousand grain weight, and total yield; a major increase was found at higher HA application rates and moderate NPK rates. Based on field experiments conducted by El-Bassiouny et al. (2014) and Mohammed et al. (2019), HA applied with NPK fertilizer significantly improved the shoot dry weight and chlorophyll content of wheat and Stevia rebaudiana; there was no significant difference in wheat plant height, spike length and yield in this trial. In a 2-year field experiment conducted in Iran to evaluate the effect of foliar application of HA and different urea levels, HA treatment significantly increased the spike number, biomass, and yield of wheat at a urea application rate of $150 \mathrm{Kg} \mathrm{ha}^{-1}$ compared to $225 \mathrm{Kg} \mathrm{ha}^{-1}$ (Nasiroleslami et al., 2021). In another 2-year field experiments carried out in Iran with canola, the interaction of different urea and HA-rich zeolite rates did not have an effect on the agronomic performance of canola, but urea and zeolite 
alone significantly increased agronomic parameters (Bybordi and Ebrahimian, 2013).

The inconsistent results observed in the aforementioned studies show that recommendation for HA use in improving crop agronomic performances can only be reliable after being tested under specific conditions. Literature suggests that combined application of HA and mineral fertilizers form complexes that slowly release nutrients and subsequent crop uptake but the interaction effect depends mostly on the HA source, application rate, and crop type (Rose et al., 2014). Therefore, it is imperative to elucidate for a particular HA source, the optimum application and $\mathrm{N}$ fertilizer rates on crop agronomic parameters in multiple crops under defined growth conditions.

\section{FACTORS AFFECTING HUMIC ACIDS EFFICIENCY}

\section{Humic Acid Source}

HA effects on soils and crops depends on the HS source (Rose et al., 2014; Gollenbeek and Van Der Weide, 2020). The source of HA applied depends on various factors such as nutritional composition, mode of production, functional group composition, and intended purpose. Among five different HA sources that were analyzed for their effectiveness on crop agronomic parameters, they followed the decreasing order; compost from manure $<$ compost from green waste $<$ soil $<$ brown coal $<$ peat (reviewed by Rose et al., 2014). HA extracted from different organic materials have different bioactivity potentials (Martinez-balmori et al., 2014). It was found that commercially-produced HA were less effective than HA produced from waste materials (Arancon et al., 2006). Jindo et al. (2020) also found that HA produced from composted materials were efficient in increasing plant agronomic and physiological activities. However, Khan et al. (2018) found no significant differences on wheat yield between treatments with HA produced from plants and coal. Different sources of HA contain different nutrient compositions and chemical structures, which can influence their performance in the soil. García et al. (2019) found different quantities of functional groups in HA obtained from Elliot soil, peat, leonardite, Su Wanee river, and Hill soil. In a pot experiment conducted by Hamad and Tantawy (2018) with three different sources of HA extracted from clayey soil, podrite and compost, sorghum root, and shoot growth correlated with amount of aromatic, aliphatic and carboxyl functional groups present in the various HA sources. Furthermore, $\mathrm{N}$ uptake was positively correlated with the high amounts of HA carboxylic functional group (Piccolo et al., 1992; Nardi et al., 2000). However, when several HA sources (lignite, soil, compost, coal, and peat) were tested for their fungicidal function, HA sources with high aromatic functional group related negatively to fungicidal function (Wei et al., 2018). This is an indication that HA source selection should be geared at a particular objective. Laskosky et al. (2020) conducted a pot experiment using three different HA-containing sources with different chemical properties; humalite, and peat which had high initial concentration of $\mathrm{N}$ and $\mathrm{P}$ compared to biochar, resulted in barley plants with significantly increased $\mathrm{N}$ and $\mathrm{P}$ concentrations. There are limited studies that evaluate and compare the effect of different HA sources on crop agronomic parameters under laboratory and field conditions, warranting further research.

\section{Application Rate}

It has been suggested that $\mathrm{HA}$ application rates are most effective under severe stress conditions (Rose et al., 2014). The effectiveness of HA application rate is also contingent on the source and crop type being grown (Olk et al., 2018). Under waterstressed conditions, plants triggered water deficit responses such as proline production. Under water-stressed field conditions, the effects of different HA application rates had a significant effect on millet yield, but the increase was not dose-dependent (Shen et al., 2020a). Similarly, HA elicited catalase and proline activity of maize seedlings under water-stressed conditions, but the increase was not dependent on the rate applied (Canellas et al., 2020). However, an earlier study by Lotfi et al. (2015) reported a HA dose-dependent increase in proline and catalase activity in rapeseed under water-stressed conditions. Under saltstressed condition, HA increased agronomic parameters (e.g., plant height, leaf area, stem diameter, chlorophyll content and yield), and proline content of bean plants (Taha and Osman, 2018). Under similar salt-stressed conditions, Yousif et al. (2020) found that, increase in agronomic parameters and proline content in maize correlated with increase in HA application rates.

Mohammed et al. (2019) found an increase in the growth and agronomic parameters of Stevia rebaudiana in a field experiment under optimal soil water and salt $\left(\mathrm{Na}^{+}, \mathrm{Ca}^{2+}\right.$, and $\mathrm{Mg}^{2+}$ ) conditions; the increase in growth and agronomic parameters correlated with increased HA application rates.

TABLE 3 | Factors and conditions that affect humic acids (HA) efficacy.

\begin{tabular}{|c|c|c|}
\hline Factors & Conditions & References \\
\hline HA sources & $\begin{array}{l}\text { Type of material extracted from } \\
\text { (soil, peat, coal, lignite, organic } \\
\text { residues etc.), nutrients } \\
\text { composition, chemical structure } \\
\text { and molecular weight. }\end{array}$ & $\begin{array}{l}\text { Rose et al., 2014; Hamad } \\
\text { and Tantawy, 2018; } \\
\text { García et al., 2019; } \\
\text { Laskosky et al., 2020 }\end{array}$ \\
\hline $\begin{array}{l}\text { Application } \\
\text { rate }\end{array}$ & $\begin{array}{l}\text { Stress conditions (saline, } \\
\text { drought, acidic, heavy metal } \\
\text { concentration), nutrients } \\
\text { composition of HA, source of } \\
\text { HA, type of crop, type of soil, } \\
\text { and environmental conditions. }\end{array}$ & $\begin{array}{l}\text { Bybordi and Ebrahimian, } \\
\text { 2013; Rose et al., 2014; } \\
\text { Lotfi et al., 2015; Olk } \\
\text { et al., 2018; Mohammed } \\
\text { et al., 2019; Baía et al., } \\
\text { 2020; Shen et al., 2020a; } \\
\text { Yousif et al., 2020; Sible } \\
\text { et al., } 2021\end{array}$ \\
\hline Soil type & $\begin{array}{l}\text { Type of clay, sand, and } \\
\text { adsorption capacity of HA }\end{array}$ & $\begin{array}{l}\text { Feng et al., 2005; Zhang } \\
\text { et al., 2013; Chen et al., } \\
\text { 2017; Singh et al., 2017; } \\
\text { Nardi et al., 2021; Sarlaki } \\
\text { et al., } 2021\end{array}$ \\
\hline Solubility & $\begin{array}{l}\text { Water, alkaline and acid } \\
\text { extractable fraction of } \mathrm{HA}\end{array}$ & $\begin{array}{l}\text { Pinton et al., 1999; } \\
\text { Schmidt and Santi, 2007; } \\
\text { Liu et al., 2008; De Melo } \\
\text { et al., 2016; Savy et al., } \\
\text { 2017; Sible et al., } 2021\end{array}$ \\
\hline
\end{tabular}


Bybordi and Ebrahimian (2013) did not find any significant difference in canola agronomic parameters following different HA application rates. In nutrient-rich HA, the rate applied will have an effect on soils and plants since an additional source of nutrients from HA will be added to the soil (Sible et al., 2021). Karakurt et al. (2009) found an increase in pepper yield after moderate HA application, but similar yields were observed between the untreated control and higher HA application rates. HA application rates is dependent on environmental and soil conditions (Table 3), source and composition, as well as crop type, making it difficult to predict its effect on different crops.

\section{Soil Type}

Soil type plays an important role in HA adsorption and decomposition. HA are efficient when retained in the soil after application without leaching (Chen et al., 2017). Sandy soils have large textures and poor structure and therefore have poor retention of external application of nutrients and other soil amendments (Sarlaki et al., 2021). Soil clay fraction, which plays a vital role in retaining HA, differs among soil types (Singh et al., 2017). The differences in the binding capacities of different clay minerals in soils affect the rate at which HA are adsorbed onto soil surfaces. Kaolinite, which is 1:1 clay interacts effectively with HA, thereby retaining them onto its surface (Al-Essa, 2019). Feng et al. (2005) and Chen et al. (2017) found increased adsorption of HA onto kaolinite surfaces compared to montmorillonite. Chen et al. (2017) also found that kaolinite adsorbed HA more than montmorillonite due to their contrasting physical and chemical characteristics. Another study by Zhang et al. (2013) evaluated the effects of HA on three clay minerals (kaolinite, montmorillonite, and illite); they found that the specific surface area of montmorillonite decreased, thereby decreasing CEC compared to other clay minerals. However, hydrogen bonding in montmorillonite increased, thereby increasing adsorption capacity for $\mathrm{NH}_{4}^{+}$.

The efficacy of HA depends on how they are able to adsorb onto clay surfaces; hence differences in clay fractions at different sites will affect $\mathrm{HA}$ function and subsequent soil properties and crop performance. For example, Tahir et al. (2011) found that HA application increased wheat agronomic parameters in non-calcareous relative to calcareous soils. Khan et al. (2018) found higher wheat spike weight and grain yield on clayey loam compared to sandy loam soil. The recent review by Nardi et al. (2021) showed that different soils have different effects on maize nitrate and ammonium uptake as well as $\mathrm{N}$ metabolism after HA application. Although Rose et al. (2014) had indicated that the soil type had little impact on HA performance, their sample size was not adequate to extrapolate the results to represent all soil types. Literature on the effects of soil types on HA efficiency have been summarized in Table 3.

\section{Solubility}

Humic acid solubility depends on the $\mathrm{pH}$ of the medium (MacCarthy et al., 1990). HA are partially soluble in water and alkaline medium but precipitate under very low $\mathrm{pH}$ (De Melo et al., 2016). Researchers claim that the extraction of HA with alkaline change their structure thereby making alkaline solutions inappropriate for studies (Kleber and Johnson, 2010), but Olk et al. (2019, and references therein) claim the opposite. HA can form complexes with soil cationic nutrients, and the solubility of these complexes can influence the release of these nutrients to crops (Sible et al., 2021). Therefore, the proportion of HA that is soluble in acid, alkaline, and water will affect the growth of crops. Pinton et al. (1999) found that watersoluble HA increased nitrate uptake by activating root plasma membrane $\mathrm{H}^{+}$ATPase. Treatment of maize root with nitrate and water-extractable HA increased nitrate uptake, resulting in upregulation of nitrate assimilation enzymes (Zanin et al., 2018). Savy et al. (2017) found that water-soluble HA extracted from giant reed increased gibberellin activity in watercress (Lepidium sativum L.) seedlings due to the presence of phenolic moieties. The application of water-soluble HA increased root surface area of Arabidopsis due to an increase in root hairs, cortical cells, and tangential walls in the endodermal cell layer (Schmidt and Santi, 2007).

Furthermore, the acid extractable fraction of $\mathrm{HA}$ can form a stable complex with cations in the soil (Liu et al., 2008; De Melo et al., 2016), thereby increasing soil nutrients availability and improving soil physical and chemical characteristics (Billingham, 2012). There are limited studies on the effect of extractable fractions of HA in laboratory experiments and no extensive research on the effect of alkali and water-extractable fraction of $\mathrm{HA}$ on the growth and agronomic performance of crops under field conditions. Therefore, more research is needed to address this knowledge gap.

\section{RECENT ADVANCES IN HUMIC ACID RESEARCH}

\section{Extraction Methods}

Efficient extraction methods of $\mathrm{HA}$ are still a challenge to many scientists. HA produced from peat, soil, and lakes limit larger field applications due to their lower quantities (Yang and Antonietti, 2020). Most commercially-produced HA are from lignite and coal due to their more extensive deposits, especially in oil producing regions. Humic acids from these sources tend to have more carbon but less oxygen and nitrogen content as well as low carboxylic and phenolic functional groups, which mostly contribute to HA physical, chemical and biological activities (Fatima et al., 2021). Recent development in HA research has focused on efficient extraction methods that produce high HA yield with many crop growthpromoting functional groups (phenolic and carboxylic groups). Pre-treatment of lignite and coal with acid breaks down the complex compounds, thus reducing them to weaker acidic functional groups (Barhoumi et al., 2019). Nitric acid $\left(\mathrm{HNO}_{3}\right)$ has been used to increase the yield of HA produced from lignite and bituminous coal following alkaline extraction (Zara et al., 2017; Boral et al., 2021; Fatima et al., 2021). In addition to increased HA yield, they also found an increase in nitrogen and oxygen contents and functional groups such as carboxylic, phenolic and amine groups. Sabar et al. (2020) have also used $\mathrm{HNO}_{3}, \mathrm{H}_{2} \mathrm{O}_{2}$, and fungal strains to increase the HA yield, molecular weight, and aromatic functional group 
in coal-derived HA. The development of efficient extraction methods is keen on increasing HA functional groups, thereby increasing HA bioavailability.

\section{Molecular Mechanisms of Humic Acids}

Humic acids are known over the past decades for their immense contribution to plant growth, agronomic parameters, stress tolerance, and soil health. The molecular mechanisms behind these positive effects on plants were not known until recently, when researchers have begun elucidating how plants respond to HA at the molecular level. Shah et al. (2018) detailed how HA contribute to plants' molecular response to growth and stress conditions in their review. In the current review, we highlight a few of the most recent developments regarding plants' molecular responses to HA. Cha et al. (2020) showed that Arabidopsis plant grown in HA up-regulated heattolerant gene and Heat-Shock Proteins (HSP); when HSP was knockout, Arabidopsis failed to withstand heat stress. Recently,
Zandonadi et al. (2019) identified plant growth promoting hormone, Alkamides in HA, which is responsible for overexpression of protein genes inducing cell division and cytokinin production in maize. The application of HA caused down-regulation of GRF gene, a drought susceptible gene in wheat, indicating that HA can serve as a signaling molecule and trigger wheat growth under drought conditions (Arslan et al., 2020). Treating maize roots with HA up-regulated putative VHS/GAT and 2-cys peroxiredoxin BAS1 genes that are involved in antioxidant functions and $\mathrm{N}$ assimilatory pathway, respectively (Nunes et al., 2019). Identifying and understanding these molecular responses triggered by $\mathrm{HA}$ will assist plant breeders to target these genes in breeding involving HA.

\section{Knowledge Gaps and Future Research Needs}

The global effort to reduce the amount of $\mathrm{N}$ fertilizers in food production systems requires the optimization of $\mathrm{N}$ fertilizer

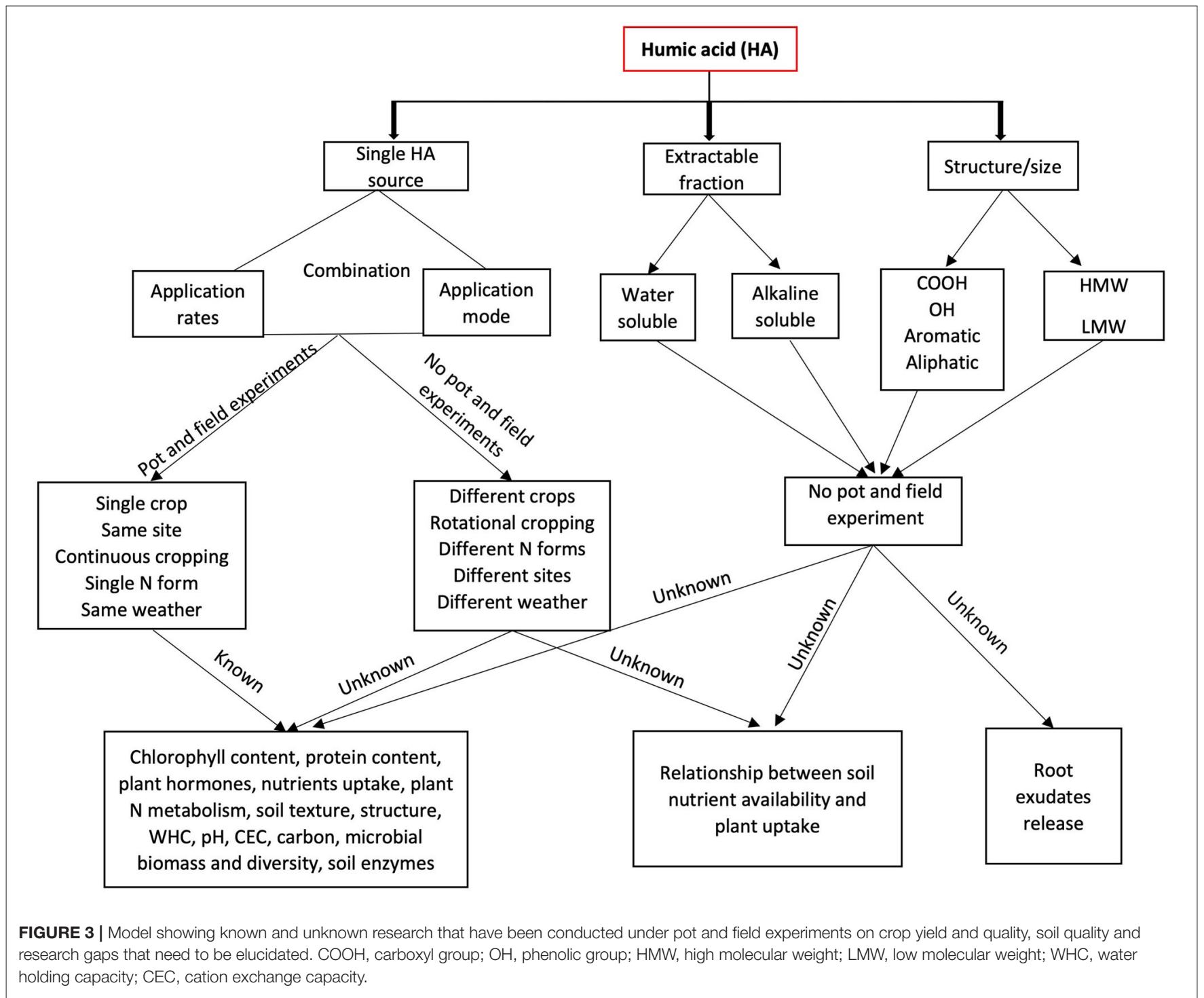


application rates in different crops, soil types, and under unpredictable climatic conditions. HS are a promising tool to further optimize fertilizer application and nitrogen use efficiency in crops. We have identified some knowledge gaps (Figure 3) that warrants further research. There are no studies that have been conducted to test a specific HA sources, their application rate and mode of application either in a series of pot or field experiments in different crops. Neither has the interaction between $\mathrm{HA}, \mathrm{N}$ forms, sites, and climatic conditions on crop yield and quality as well as soil health and quality been fully understood. We also identified research gaps in the relationship between HA-soil-plant nutrient availability and plant uptake under different experimental conditions. Such knowledge will help agronomists and crop producers understand how HA interacts with different crops, forming the basis for planning sustainable cropping systems. This review identified that the water and alkaline soluble fractions as well as the chemical and molecular structures of $\mathrm{HA}$ have not been assessed under both pot and field experiments for their effects on crop yield/ quality and soil health. Furthermore, there is a lack of information on how HA chemical and molecular structures (carboxyl, phenolic, aliphatic, aromatic functional groups, HMW, and LMW compounds) affect yield and crop quality, soil quality parameters, soil nutrient availability, plant uptake, and rhizosphere root exudates. Research on these topics will benefit industries involved in HA production to focus on HA fraction and functional groups capable of conferring significant benefits to crops. Most of the laboratory and field trials on HA effects on protein concentration have been conducted by analyzing the grain protein concentration but data are still limited, preventing solid conclusions. Also, data on the mechanisms on how HA contribute to $\mathrm{N}$ assimilation and protein production are still lacking considering that most of the cereal and pulse crops cultivated are required to attain high protein contents. Therefore, understanding how HA increases protein concentration in crops will be crucial for HA industry players and crop producers.

\section{REFERENCES}

Ahmed, O. H., Aminuddin, H., and Husni, M. H. A. (2006). Reducing ammonia loss from urea and improving soil-exchangeable ammonium retention through mixing triple superphosphate, humic acid and zeolite. Soil Use Manag. 22, 315-319. doi: 10.1111/j.1475-2743.2006.00040.x

Akinremi, O. O., Janzen, H. H., Lemke, R. L., and Larney, F. J. (2000). Response of canola, wheat and green beans to leonardite additions. Can. J. Soil Sci. 80, 437-443. doi: 10.4141/S99-058

Albiach, R., Canet, R., Pomares, F., and Ingelmo, F. (2001). Organic matter components and aggregate stability after the application of different amendments to a horticultural soil. Bioresour. Technol. 76, 125-129. doi: 10.1016/S0960-8524(00)00090-0

Al-Essa, K. (2019). Adsorption of humic acid onto kaolinite clay: a mini-review. J. Chem. Sci. Eng. 2, 53-57.

AL-Kanani, T., MacKenzie, A. F., and Blenkhorn, H. (1990). Volatilization of ammonia from urea-ammonium nitrate solutions as influenced by organic and inorganic additives. Fertil. Res. 23, 113-119. doi: 10.1007/BF01063338

Arancon, N. Q., Edwards, C. A., Lee, S., and Byrne, R. (2006). Effects of humic acids from vermicomposts on plant growth. Eur. J. Soil Biol. 42, 65-69. doi: 10.1016/j.ejsobi.2006.06.004

\section{CONCLUSIONS}

This review has revealed that HA application has potential significant effects on crop agronomic performance and soil quality parameters. This review identified several factors that affect HA performance in crops and soils; the most influential of them is the HA source. The HA chemical and molecular structure, solubility, and other factors such as application rate, soil, and crop type also affect HA effects on crop performance. This review via the evaluation of both laboratory and field experiments, identified the effects of HA on crop agronomic performance and soil health parameters. Knowledge gaps in HA studies have been identified in this review. More research is needed to optimize the combined effect of different HA application rates and mineral fertilizers on crop performance and soil quality parameters under defined field conditions; more importantly, long-term studies involving different soil types, crops and weather patterns in warranted to truly exploit the benefits of HS.

\section{AUTHOR CONTRIBUTIONS}

KA: writing the draft of the manuscript and compilation of the literature. LG and MT: provided detailed comments and guidance and edited the manuscript. All authors contributed to the article and approved the submitted version.

\section{FUNDING}

This research was financially supported by: Canadian Agricultural Partnership (CAP) - Project \# 2022N004RC/RES0055374, Prairie Mines and Royalty ULC (PMRU) (File No. 2022N004R/RES0055180) and Results Driven Agriculture Research (RDAR) - Project \# 2022N004R/RES0054511. Many thanks go to the Western Grains Research Foundation for funding the position of the LG, making it possible for this manuscript to be produced.

Arjumend, T., Abbasi, M. K., and Rafique, E. (2015). Effects of lignite-derived Humic acid on some selected soil properties, growth and nutrient uptake of wheat (Triticum Aestivum 1.) grown under greenhouse conditions. Pakistan J. Bot. 47, 2231-2238.

Arslan, E., Agar, G., and Aydin, M. (2020). Humic acid as a biostimulant in improving drought tolerance in wheat: the expression patterns of drought-related genes. Plant Mol. Biol. Report. 39, 508-519. doi: 10.1007/s11105-020-01266-3

Atiyeh, R. M., Lee, S., Edwards, C. A., Arancon, N. Q., and Metzger, J. D. (2002). The influence of humic acids derived from earthworm. Bioresour. Technol. 84, 7-14. doi: 10.1016/S0960-8524(02) 00017-2

Baía, D. C., Olivares, F. L., Zandonadi, D. B., de Paula Soares, C., Spaccini, R., and Canellas, L. P. (2020). Humic acids trigger the weak acids stress response in maize seedlings. Chem. Biol. Technol. Agric. 7, 31. doi: 10.1186/s40538-020-00193-5

Barhoumi, A., Ncib, S., Chibani, A., Brahmi, K., Bouguerra, W., and Elaloui, E. (2019). High-rate humic acid removal from cellulose and paper industry wastewater by combining electrocoagulation process with adsorption onto granular activated carbon. Ind. Crops Prod. 140, 111715. doi: 10.1016/j.indcrop.2019.111715 
Barth, G., Otto, R., Almeida, R. F., Cardoso, E. J. B. N., Cantarella, H., and Vitti, G. C. (2020). Conversion of ammonium to nitrate and abundance of ammonium-oxidizing-microorganism in tropical soils with nitrification inhibitor. Sci. Agric. 77, 2-6. doi: 10.1590/1678-992x-20180370

Billingham, K. L. (2012). "Humic products-potential or presumption for agriculture? Can humic products improve my soil?" in 27th Annual Conference (Orange, NSW: Grassland Society of NSW Inc.).

Boral, P., Varma, A. K., and Maity, S. (2021). Nitration of Jharia basin coals, India: a study of structural modifications by XRD and FTIR techniques. Int. J. Coal Sci. Technol. 8, 1034-1053. doi: 10.1007/s40789-021-00422-8

Bulut, F., and Akinci, S. (2010). The effect of salinity on growth and nutrient composition in broad bean (Vicia faba L.) seedlings. Fresenius Environ. Bull. $19,2901-2910$

Bybordi, A., and Ebrahimian, E. (2013). Growth, yield and quality components of canola fertilized with urea and zeolite. Commun. Soil Sci. Plant Anal. 44, 2896-2915. doi: 10.1080/00103624.2013.823986

Canellas, L. P., Canellas, N. O. A., Luiz Eduardo, L. E. S., Olivares, F. L., and Piccolo, A. (2020). Plant chemical priming by humic acids. Chem. Biol. Technol. Agric. 7, 12. doi: 10.1186/s40538-020-00178-4

Canellas, L. P., Piccolo, A., Dobbss, L. B., Spaccini, R., Olivares, F. L., Zandonadi, D. B., et al. (2010). Chemical composition and bioactivity properties of size-fractions separated from a vermicompost humic acid. Chemosphere 78, 457-466. doi: 10.1016/j.chemosphere.2009.10.018

Cha, J. Y., Kang, S. H., Ali, I., Lee, S. C., and Ji, M. G. (2020). Humic acid enhances heat stress tolerance via transcriptional activation of heat - shock proteins in arabidopsis. Sci. Rep. 10, 15042. doi: 10.1038/s41598-020-71701-8

Chen, H., Koopal, L. K., Xiong, J., Avena, M., and Tan, W. (2017). Mechanisms of soil humic acid adsorption onto montmorillonite and kaolinite. J. Colloid Interface Sci. 504, 457-467. doi: 10.1016/j.jcis.2017.05.078

Chen, Y., Magen, H., and Clapp, C. E. (2004). Mechanisms of plant growth stimulation by humic substances: The role of organo-iron complexes. Soil Sci. Plant Nutr. 50, 1089-1095. doi: 10.1080/00380768.2004.10408579

De Melo, B. A. G., Motta, F. L., and Santana, M. H. A. (2016). Humic acids: Structural properties and multiple functionalities for novel technological developments. Mater. Sci. Eng. C 62, 967-974. doi: 10.1016/j.msec.2015.12.001

Delfine, S., Tognetti, R., and Ersilio Desiderio, A. A. (2005). Effect of foliar application of $\mathrm{N}$ and humic acids on growth and yield of durum wheat. Agron. Sustain. Dev. 25, 183-191. doi: 10.1051/agro:2005017

Dong, L., Córdova-Kreylos, A. L., Yang, J., Yuan, H., and Scow, K. M. (2009). Humic acids buffer the effects of urea on soil ammonia oxidizers and potential nitrification. Soil Biol. Biochem. 41, 1612-1621. doi: 10.1016/j.soilbio.2009.04.023

Dungait, J. A. J., Hopkins, D. W., Gregory, A. S., and Whitmore, A. P. (2012). Soil organic matter turnover is governed by accessibility not recalcitrance. Glob. Chang. Biol. 18, 1781-1796. doi: 10.1111/j.1365-2486.2012.02665.x

El-Bassiouny, H. S. M., Bakry, B. A., El-Monem Attia, A. A., and Abd Allah, M. M. (2014). Physiological role of humic acid and nicotinamide on improving plant growth, yield, and mineral nutrient of wheat (Triticum durum L.) grown under newly reclaimed sandy soil. Agric. Sci. $05,687-700$. doi: 10.4236/as.2014.58072

Elmajdoub, B., Barnett, S., and Marschner, P. (2014). Response of microbial activity and biomass in rhizosphere and bulk soils to increasing salinity. Plant Soil 381, 297-306. doi: 10.1007/s11104-014-2127-4

Fan, H., mei, Wang, X., wen, Sun, X., Li, Y., ying, Sun, X., zhi, and Zheng, C., shu (2014). Effects of humic acid derived from sediments on growth, photosynthesis and chloroplast ultrastructure in chrysanthemum. Sci. Hortic. 177, 118-123. doi: 10.1016/j.scienta.2014.05.010

Fatima, N., Jamal, A., Huang, Z., Liaquat, R., Ahamad, B., Haider, R., et al. (2021). Extraction and chemical characterization of humic acid from nitric acid treated lignite and bituminous coal samples. Sustainability. 13, 8969. doi: $10.3390 /$ su13168969

Feng, X., Simpson, A. J., and Simpson, M. J. (2005). Chemical and mineralogical controls on humic acid sorption to clay mineral surfaces. Org. Geochem. 36, 1553-1566. doi: 10.1016/j.orggeochem.2005.06.008

Fontaine, S., Barot, S., Barré, P., Bdioui, N., Mary, B., and Rumpel, C. (2007). Stability of organic carbon in deep soil layers controlled by fresh carbon supply. Nature 450, 277-280. doi: 10.1038/nature06275
Fuentes, M., Baigorri, R., González-Gaitano, G., and García-Mina, J. M. (2018). New methodology to assess the quantity and quality of humic substances in organic materials and commercial products for agriculture. J. Soils Sediments 18, 1389-1399. doi: 10.1007/s11368-016-1514-2

Garciá, A. C., De Souza, L. G. A., Pereira, M. G., Castro, R. N., Garciá-Mina, J. M., Zonta, E., et al. (2016). Structure-property-function relationship in humic substances to explain the biological activity in plants. Sci. Rep. 6, 20798. doi: $10.1038 /$ srep20798

García, A. C., van Tol de Castro, T. A., Santos, L. A., Tavares, O. C. H., Castro, R. N., Berbara, R. L. L., et al. (2019). Structure-property-function relationship of humic substances in modulating the root growth of plants: a review. J. Environ. Qual. 48, 1622-1632. doi: 10.2134/jeq2019.01.0027

Gerke, J. (2018). Concepts and misconceptions of humic substances as the stable part of soil organic matter: a review. Agronomy 8, 76. doi: 10.3390/agronomy8050076

Giannouli, A., Kalaitzidis, S., Siavalas, G., Chatziapostolou, A., Christanis, K., Papazisimou, S., et al. (2009). Evaluation of Greek low-rank coals as potential raw material for the production of soil amendments and organic fertilizers. Int. J. Coal Geol. 77, 383-393. doi: 10.1016/j.coal.2008.07.008

Gollenbeek, L., and Van Der Weide, R. (2020). Prospects for Humic Acid Products From Digestate in the Netherlands. Report WPR-867, 5-40. doi: $10.18174 / 541280$

Grinhut, T., Hadar, Y., and Chen, Y. (2007). Degradation and transformation of humic substances by saprotrophic fungi: processes and mechanisms. Fungal Biol. Rev. 21, 179-189. doi: 10.1016/j.fbr.2007.09.003

Gümüs, I., and Seker, C. (2015). Influence of humic acid applications on modulus of rupture, aggregate stability, electrical conductivity, carbon and nitrogen content of a crusting problem soil. Solid Earth 6, 1231-1236. doi: 10.5194/se-6-1231-2015

Haghighi, M., Kafi, M., and Fang, P. (2012). Photosynthetic activity and $\mathrm{n}$ metabolism of lettuce as affected by humic acid. Int. J. Veg. Sci. 18, 182-189. doi: $10.1080 / 19315260.2011 .605826$

Hamad, M. M., and Tantawy, M. F. A. (2018). Effect of different humic acids sources on the plant growth, cal- cium and iron utilization by sorghum. Egypt. J. Soil. Sci. 58, 291-307. doi: 10.21608/EJSS.2018.3559.1173

Hayes, M. H. B., and Swift, R. S. (2020). Vindication of humic substances as a key component of organic matter in soil and water. Adv. Agron. 163, 1-37. doi: 10.1016/bs.agron.2020.05.001

$\mathrm{Hu}, \mathrm{J} ., \mathrm{Wu}, \mathrm{J}$., and Qu, X. (2019). Effects of organic wastes on labile organic carbon in semiarid soil under plastic mulched drip irrigation. Arch. Agron. Soil Sci. 65, 1873-1884. doi: 10.1080/03650340.2019.1579903

Imbufe, A. U., Patti, A. F., Burrow, D., Surapaneni, A., Jackson, W. R., and Milner, A. D. (2005). Effects of potassium humate on aggregate stability of two soils from Victoria, Australia. Geoderma 125, 321-330. doi: 10.1016/. geoderma.2004.09.006

Jindo, K., Olivares, F. L., Malcher, D. J., da, P., and Sánchez-Monedero, M. A., Kempenaar, C., et al. (2020). From lab to field: role of humic substances under open-field and greenhouse conditions as biostimulant and biocontrol agent. Front. Plant Sci. 11, 426. doi: 10.3389/fpls.2020.00426

Karakurt, Y., Unlu, H., Unlu, H., and Padem, H. (2009). The influence of foliar and soil fertilization of humic acid on yield and quality of pepper. Acta Agric. Scand. Sect. B Soil Plant Sci. 59, 233-237. doi: 10.1080/09064710802022952

Kelapa, T., and Banyuasin, K. (2016). Effects of humic substances on plant growth and mineral nutrients uptake of wheat under conditions of salinity. Asian J. Crop Sci. 1, 87-95. doi: 10.3923/ajcs.2009.87.95

Khan, R. U., Khan, M. Z., Khan, A., Saba, S., Hussain, F., and Jan, I. U. (2018). Effect of humic acid on growth and crop nutrient status of wheat on two different soils. J. Plant Nutr. 41, 453-460. doi: 10.1080/01904167.2017.1385807

Khan, R. U., Rashid, A., and Khan, M. S. (2010). Impact of humic acid and chemical fertilizer application on growth and grain yield of rainfed wheat (Triticum aestivum L.). Pakistan J. Agric. Res. 23, 113-121.

Kleber, M., and Johnson, M. G. (2010). Advances in understanding the molecular structure of soil organic matter: implications for interactions in the environment. Adv. Agron. 106, 78-118. doi: 10.1016/S0065-2113(10)06003-7

Laskosky, J. D., Mante, A. A., Zvomuya, F., Amarakoon, I., and Leskiw, L. (2020). A bioassay of long-term stockpiled salvaged soil amended with biochar, peat, and humalite. Agrosyst. Geosci. Environ. 3, e20068. doi: 10.1002/agg2.20068 
Li, Y., Fang, F., Wei, J., Wu, X., Cui, R., Li, G., et al. (2019). Humic acid fertilizer improved soil properties and soil microbial diversity of continuous cropping peanut: A three-year experiment. Sci. Rep. 9, 1-9. doi: 10.1038/s41598-019-48620-4

Liu, S., Lim, M., Fabris, R., Chow, C., Chiang, K., Drikas, M., et al. (2008). Removal of humic acid using $\mathrm{TiO} 2$ photocatalytic process - fractionation and molecular weight characterisation studies. Chemosphere 72, 263-271. doi: 10.1016/j.chemosphere.2008.01.061

Loss, A., Pereira, M. G., Perin, A., Beutler, S. J., and Anjos, L. H. C. (2013). Oxidizable carbon and humic substances in rotation systems with brachiaria/livestock and pearl millet/no livestock in the Brazilian Cerrado. Spanish J. Agric. Res. 11, 217-231. doi: 10.5424/sjar/2013111-3416

Lotfi, R., Kouchebagh, P. G., and Khoshvaghti, H. (2015). Biochemical and physiological responses of Brassica napus plants to humic acid under water stress. Russ. J. Plant Physoil. 62, 480-486. doi: 10.1134/S1021443715040123

MacCarthy, P., Malcolm, R. L., Clapp, C. E., and Bloom, P. R. (eds.). (1990). "An introduction to soil humic substances," in Humic Substances in Soil and Crop Sciences: Selected Readings, 1-12. Madison, WI: Soil Science Society of America. doi: 10.2136/1990.humicsubstances

Mackowiak, C. L., Grossl, P. R., and Bugbee, B. G. (2001). Beneficial effects of humic acid on micronutrient availability to wheat. Soil Sci. Soc. Am. J. 65, 1744-1750. doi: 10.2136/sssaj2001.1744

Maji, D., Misra, P., Singh, S., and Kalra, A. (2017). Humic acid rich vermicompost promotes plant growth by improving microbial community structure of soil as well as root nodulation and mycorrhizal colonization in the roots of Pisum sativum. Appl. Soil Ecol. 110, 97-108. doi: 10.1016/j.apsoil.2016.10.008

Martinez-balmori, D., Spaccini, R., Novotny, E. H., and Canellas, L. P. (2014). Molecular characteristics of humic acids isolated from vermicomposts and their relationship to bioactivity. J. Agri. Food Chem. 62, 11412-11419. doi: $10.1021 /$ jf504629c

Mirza, M. A., Agarwal, S. P., Rahman, M. A., Rauf, A., Ahmad, N., Alam, A., et al. (2011). Role of humic acid on oral drug delivery of an antiepileptic drug. Drug Dev. Ind. Pharm. 37, 310-319. doi: 10.3109/03639045.2010.512011

Mohammed, M., Meawad, A., El-Mogy, E., and Abdelkader, M. (2019). Growth, yield components and chemical constituents of Stevia rebaudiana Bert. as affected by humic acid and npk fertilization rates. Zagazig J. Agric. Res. 46, 13-26. doi: 10.21608/zjar.2019.40172

Mukherjee, A., Lal, R., and Zimmerman, A. R. (2014). Impacts of 1.5-year field aging on biochar, humic acid, and water treatment residual amended soil. Soil Sci. 179, 333-339. doi: 10.1097/SS.0000000000000076

Nandakumar, R., Saravanan, A., Singaram, P., and Chandrasekaran, B. (2004). Effect of lignite humic acid on soil nutrient availability at different growth stages of rice grown on vertisols and alfisols. Acta Agron. Hungarica 52, 227-235. doi: 10.1556/AAgr.52.2004.3.3

Nardi, S., Ertani, A., and Francioso, O. (2017). Soil-root cross-talking: the role of humic substances. J. Plant Nutr. Soil Sci. 180, 5-13. doi: 10.1002/jpln.201600348

Nardi, S., Pizzeghello, D., Gessa, C., Ferrarese, L., Trainotti, L., and Casadoro, G. (2000). A low molecular weight humic fraction on nitrate uptake and protein synthesis in maize seedlings. Soil Biol. Biochem. 32, 415-419. doi: 10.1016/S0038-0717(99)00168-6

Nardi, S., Pizzeghello, D., Muscolo, A., and Vianello, A. (2002). Physiological effects of humic substances on higher plants. Soil Biol. Biochem. 34, 1527-1536. doi: 10.1016/S0038-0717(02)00174-8

Nardi, S., Schiavon, M., and Francioso, O. (2021). Chemical structure and biological activity of humic substances define their role as plant growth promoters. Molecules 26, 2256. doi: 10.3390/molecules26082256

Nasiroleslami, E., Mozafari, H., Sadeghi-Shoae, M., Habibi, D., and Sani, B. (2021). Changes in yield, protein, minerals, and fatty acid profile of wheat (Triticum aestivum L.) under fertilizer management involving application of nitrogen, humic acid, and seaweed extract. J. Soil Sci. Plant Nutr. 21, 2642-2651. doi: 10.1007/s42729-021-00552-7

Nikbakht, A., Kafi, M., Babalar, M., Xia, Y. P., Luo, A., and Etemadi, N. A. (2008). Effect of humic acid on plant growth, nutrient uptake, and postharvest life of gerbera. J. Plant Nutr. 31, 2155-2167. doi: 10.1080/01904160802462819

Nunes, R. O., Domiciano, G. A., Alves, W. S., Claudia, A., Melo, A., Cesar, F., et al. (2019). Evaluation of the effects of humic acids on maize root architecture by label-free proteomics analysis. Sci. Rep. 9, 12019. doi: $10.1038 / \mathrm{s} 41598-019-48509-2$
Oelmann, Y., Kreutziger, Y., Bol, R., and Wilcke, W. (2007). Nitrate leaching in soil: Tracing the $\mathrm{NO}_{3}^{-}$sources with the help of stable $\mathrm{N}$ and $\mathrm{O}$ isotopes. Soil Biol. Biochem. 39, 3024-3033. doi: 10.1016/j.soilbio.2007.05.036

Olaetxea, M., Mora, V., Baigorri, R., Zamarreño, A. M., and García-Mina, J. M. (2020). The singular molecular conformation of humic acids in solution influences their ability to enhance root hydraulic conductivity and plant growth. Molecules 26, 7-10. doi: 10.3390/molecules26010003

Olk, D. C., Bloom, P. R., Nobili, M., De, C., hen, Y., Mcknight, D. M., et al. (2019). Using humic fractions to understand natural organic matter processes in soil and water: Selected studies and applications. J. Environ. Qual. 48, 1633-1643. doi: $10.2134 /$ jeq2019.03.0100

Olk, D. C., Dinnes, D. L., Rene Scoresby, J., Callaway, C. R., and Darlington, J. W. (2018). Humic products in agriculture: potential benefits and research challenges-a review. J. Soils Sediments 18, 2881-2891. doi: 10.1007/s11368-018-1916-4

Pertusatti, J., and Prado, A. G. S. (2007). Buffer capacity of humic acid: Thermodynamic approach. J. Colloid Interface Sci. 314, 484-489. doi: 10.1016/j.jcis.2007.06.006

Piccolo, A., Nardi, S., and Concheri, G. (1992). Structural characteristics of humic substances as related to nitrate uptake and growth regulation in plant systems. Soil Biol. Biochem. 24, 373-380. doi: 10.1016/0038-0717(92)90197-6

Piccolo, A., Pietramellara, G., and Mbagwu, J. S. C. (1997). Use of humic substances as soil conditioners to increase aggregate stability. Geoderma 75, 267-277. doi: 10.1016/S0016-7061(96)00092-4

Pinton, R., Cesco, S., Iacolettig, G., Astolfi, S., and Varanini, Z. (1999). Modulation of $\mathrm{NO}_{3}^{-}$uptake by water-extractable humic substances: Involvement of root plasma membrane $\mathrm{H}^{+}$ATPase. Plant Soil 215, 155-161. doi: 10.1023/A:1004752531903

Rose, M. T., Patti, A. F., Little, K. R., Brown, A. L., Jackson, W. R., and Cavagnaro, T. R. (2014). A meta-analysis and review of plant-growth response to humic substances: Practical implications for agriculture. Adv. Agron. 124, 37-89. doi: 10.1016/B978-0-12-800138-7.00002-4

Rupiasih, N. N. (2005). A review: Compositions, structures, properties and applications of humic substances. J. Adv. Sci. Technol. 8, 16-25.

Sabar, M. A., Ali, M. I., Fatima, N., Malik, A. Y., Jamal, A., Liaquat, R., et al. (2020). Evaluation of humic acids produced from Pakistani subbituminous coal by chemical and fungal treatments. Fuel 278, 118301. doi: 10.1016/j.fuel.2020.118301

Sarlaki, E., Sharif Paghaleh, A., Kianmehr, M. H., and Asefpour Vakilian, K. (2021). Valorization of lignite wastes into humic acids: Process optimization, energy efficiency and structural features analysis. Renew. Energy 163, 105-122. doi: 10.1016/j.renene.2020.08.096

Saruhan, V., Kuşvuran, A., and Babat, S. (2011). The effect of different humic acid fertilization on yield and yield components performances of common millet (Panicum miliaceum L.). Sci. Res. Essays 6, 663-669.

Savy, D., Canellas, L., Vinci, G., Cozzolino, V., and Piccolo, A. (2017). Humic-like water-soluble lignins from giant reed (Arundo donax L.) display hormone-like activity on plant growth. J. Plant Growth Regul. 36, 995-1001. doi: 10.1007/s00344-017-9696-4

Schmidt, W., and Santi, S. (2007). Water-extractable humic substances alter root development and epidermal cell pattern in Arabidopsis. Plant Soil 300, 259-267. doi: 10.1007/s11104-007-9411-5

Shah, Z. H., Rehman, H. M., Akhtar, T., Alsamadany, H., Hamooh, B. T., Mujtaba, T., et al. (2018). Humic substances: determining potential molecular regulatory processes in plants. Front. Plant Sci. 9, 263. doi: 10.3389/fpls.2018.00263

Sharma, S. B., Sayyed, R. Z., Trivedi, M. H., and Gobi, T. A. (2013). Phosphate solubilizing microbes: Sustainable approach for managing phosphorus deficiency in agricultural soils. Springerplus 2, 587. doi: 10.1186/2193-1801-2-587

Shen, J., Guo, M., Wang, Y., Yuan, X., Dong, S., Song, X., et al. (2020a). An investigation into the beneficial effects and molecular mechanisms of humic acid on foxtail millet under drought conditions. PLOS ONE 15, e0234029. doi: 10.1371/journal.pone.0234029

Shen, Y., Lin, H., Gao, W., and Li, M. (2020b). The effects of humic acid urea and polyaspartic acid urea on reducing nitrogen loss compared with urea. J. Sci. Food Agric. 100, 4425-4432. doi: 10.1002/jsfa.10482

Sible, C. N., Seebauer, J. R., and Below, F. E. (2021). Plant biostimulants: a categorical review, their implications for row crop production, and relation 
to soil health indicators. Agronomy 11, 1297. doi: 10.3390/agronomy110 71297

Singh, M., Sarkar, B., Hussain, S., Ok, Y. S., Bolan, N. S., and Churchman, G. J. (2017). Influence of physico-chemical properties of soil clay fractions on the retention of dissolved organic carbon. Environ. Geochem. Health 39, 1335-1350. doi: 10.1007/s10653-017-9939-0

Spaccini, R., Piccolo, A., Conte, P., Haberhauer, G., and Gerzabek, M. H. (2002). Increased soil organic carbon sequestration through hydrophobic protection by humic substances. Soil Biol. Biochem. 34, 1839-1851. doi: 10.1016/S0038-0717(02)00197-9

Taha, S. S., and Osman, A. S. (2018). Influence of potassium humate on biochemical and agronomic attributes of bean plants grown on saline soil. J. Hortic. Sci. Biotechnol. 93, 545-554. doi: 10.1080/14620316.2017.146960

Tahir, M. M., Khurshid, M., Khan, M. Z., Abbasi, M. K., and Kazmi, M. H. (2011). Lignite-derived humic acid effect on growth of wheat plants in different soils. Pedosphere 21, 124-131. doi: 10.1016/S1002-0160(10)60087-2

Tan, X. W., Ikeda, H., and Oda, M. (2000). Effects of nickel concentration in the nutrient solution on the nitrogen assimilation and growth of tomato seedlings in hydroponic culture supplied with urea or nitrate as the sole nitrogen source. Sci. Hortic. 84, 265-273. doi: 10.1016/S0304-4238(99)00107-7

Tavares, O. C. H., Santos, L. A., Lima de Araújo, O. J., Coelho Bucher, C. P., García, A. C., Arruda, L. N., et al. (2019). Humic acid as a biotechnological alternative to increase $\mathrm{N}-\mathrm{NO}_{3}^{-}$or N-NH $\mathrm{N}_{4}^{+}$uptake in rice plants. Biocatal. Agric. Biotechnol. 20, 101226. doi: 10.1016/j.bcab.2019.101226

Tomar, J. S., and MacKenzie, A. F. (1984). Effects of catechol and p-benzoquinone on the hydrolysis of urea and energy barriers of urease activity in Soils. Can. J. Soil Sci. 64, 51-60. doi: 10.4141/cjss84-005

Ups, S. H., Leidi, E. O., Silberbush, M., Soares, M. I. M., and Lewis, O. E. M. (1990). Physiological aspects of ammonium and nitrate fertilization. J. Plant Nutr. 13, 1271-1289. doi: 10.1080/01904169009364151

Vaccaro, S., Ertani, A., Nebbioso, A., Muscolo, A., Quaggiotti, S., Piccolo, A., et al. (2015). Humic substances stimulate maize nitrogen assimilation and amino acid metabolism at physiological and molecular level. Chem. Biol. Technol. Agric. 2, 5. doi: 10.1186/s40538-015-0033-5

van Tol de Castro, T. A., Berbara, R. L. L., Tavares, O. C. H., Mello, D. F., and da, G., Pereira, E. G. (2021). Humic acids induce a eustress state via photosynthesis and nitrogen metabolism leading to a root growth improvement in rice plants. Plant Physiol. Biochem. 162, 171-184. doi: 10.1016/j.plaphy.2021.02.043

Wei, S., Wu, M., Li, G., Liu, M., Jiang, C., and Li, Z. (2018). Fungistatic activity of multiorigin humic acids in relation to their chemical structure. J. Agric. Food Chem. 66, 7514-7521. doi: 10.1021/acs.jafc.8b 01931

Wiesler, F., Hund-Rinke, K., Gäth, S., George, E., Greef, J. M., Hölzle, L. E., et al. (2016). Anwendung von organischen Düngern und organischen Reststoffen in der Landwirtschaft. Berichte uber Landwirtschaft 94, 1. doi: 10.12767/buel.v94i1.124

Wood, S. A. (1996). The role of humic substances in the transport and fixation of metals of economic interest (Au, Pt, Pd, U, V). Ore Geol. Rev. 11, 1-31. doi: 10.1016/0169-1368(95)00013-5

Wu, S., Li, R., Peng, S., Liu, Q., and Zhu, X. (2017). Effect of humic acid on transformation of soil heavy metals. IOP Conf. Ser. Mater. Sci. Eng. 207, 012089. doi: 10.1088/1757-899X/207/1/012089

Yamaguchi, T., Takei, T., Yazawa, Y., Wong, M. T. F., Gilkes, R. J., and Swift, R. S. (2004). Effect of humic acid, sodium, and calcium additions on the formation of water-stable aggregates in Western Australian wheatbelt soils. Aust. J. Soil Res. 42, 435-439. doi: 10.1071/SR03053
Yang, F., and Antonietti, M. (2020). The sleeping giant: A polymer view on humic matter in synthesis and applications. Prog. Polym. Sci. 100, 101182. doi: 10.1016/j.progpolymsci.2019.101182

Yang, F., Tang, C., and Antonietti, M. (2021). Natural and artificial humic substances to manage minerals, ions, water, and soil microorganisms. Chem. Soc. Rev. 50, 6221-6239. doi: 10.1039/D0CS01363C

Yousif, A., Ali, A., Eldeen, M., Ibrahim, H., Zhou, G., Eltyb, N., et al. (2020). Exogenous jasmonic acid and humic acid increased salinity tolerance of sorghum. Agron. J. 112, 871-884. doi: 10.1002/agj2.20072

Zandonadi, D. B., Roberto, C., Matos, R., Castro, R. N., and Spaccini, R. (2019). Alkamides: a new class of plant growth regulators linked to humic acid bioactivity. Chem. Biol. Technol. Agric. 6, 23. doi: 10.1186/s40538-019-0161-4

Zanin, L., Tomasi, N., Cesco, S., Varanini, Z., and Pinton, R. (2019). Humic substances contribute to plant iron nutrition acting as chelators and biostimulants. Front. Plant Sci. 10, 675. doi: 10.3389/fpls.2019.00675

Zanin, L., Tomasi, N., Zamboni, A., Sega, D., Varanini, Z., and Pinton, R. (2018). Water-extractable humic substances speed up transcriptional response of maize roots to nitrate. Environ. Exp. Bot. 147, 167-178. doi: 10.1016/j.envexpbot.2017.12.014

Zara, M., Ahmad, Z., Akhtar, J., Shahzad, K., Sheikh, N., and Munir, S. (2017). Extraction and characterization of humic acid from Pakistani lignite coals. Energy Sourc. 39, 1159-1166. doi: 10.1080/15567036.2017.1307886

Zhang, S., Qin, Y., uan, L., Li, W., Lin, Z. an, Li, Y., Ting, H., et al. (2019). Effects of urea enhanced with different weathered coal-derived humic acid components on maize yield and fate of fertilizer nitrogen. J. Integr. Agric. 18, 656-666. doi: 10.1016/S2095-3119(18)61950-1

Zhang, W. Z., Chen, X. Q., Zhou, J. M., Liu, D. H., Wang, H. Y., and Du, C. W. (2013). Influence of humic acid on interaction of ammonium and potassium ions on clay minerals. Pedosphere 23, 493-502. doi: 10.1016/S1002-0160(13)60042-9

Zhou, L., Monreal, C. M., Xu, S., McLaughlin, N. B., Zhang, H., Hao, G., et al. (2019). Effect of bentonite-humic acid application on the improvement of soil structure and maize yield in a sandy soil of a semi-arid region. Geoderma 338, 269-280. doi: 10.1016/j.geoderma.2018.12.014

Zhu, J., Li, M., and Whelan, M. (2018). Phosphorus activators contribute to legacy phosphorus availability in agricultural soils: a review. Sci. Total Environ. 612, 522-537. doi: 10.1016/j.scitotenv.2017.08.095

Conflict of Interest: The authors declare that the research was conducted in the absence of any commercial or financial relationships that could be construed as a potential conflict of interest.

Publisher's Note: All claims expressed in this article are solely those of the authors and do not necessarily represent those of their affiliated organizations, or those of the publisher, the editors and the reviewers. Any product that may be evaluated in this article, or claim that may be made by its manufacturer, is not guaranteed or endorsed by the publisher.

Copyright (C) 2022 Ampong, Thilakaranthna and Gorim. This is an open-access article distributed under the terms of the Creative Commons Attribution License (CC $B Y)$. The use, distribution or reproduction in other forums is permitted, provided the original author(s) and the copyright owner(s) are credited and that the original publication in this journal is cited, in accordance with accepted academic practice. No use, distribution or reproduction is permitted which does not comply with these terms. 